\title{
PENYUSUNAN MASTERPLAN PENGEMBANGAN KAWASAN AGROPOLITAN KABUPATEN PROBOLINGGO TAHUN 2017
}

\author{
Markus Patiung \\ markuspatiung@uwks.ac.id \\ Dosen Program Studi Agribisnis \\ Fakultas Pertanian \\ Universitas Wijaya Kusuma Surabaya
}

\begin{abstract}
ABSTRAK
Penelitian ini dengan Judul Penyusunan Masterplan Pengembangan Kawasan Agropolitan Kabupaten Probolinggo adalah untuk mewujudkan suatu kawasan menjadi kawasan agropolitan yang mandiri diperlukan suatu konsep perencanaan yang terstruktur dan berkelanjutan.

Metode yang digunakan dalam penelitian ini adalah Analisis SWOT (Streght, Weakness, Opportunity, Thread) digunakan untuk mengetahui kekuatan, kelemahan, peluang dan ancaman yang dihadapi dalam pengembangan kawasan agropolitan di Kabupaten Probolinggo.

Hasil Penelitian Agropolitan KabupatenProbolinggo ini dapat ditetapkan bahwa: Kawasan ini sesuai dengan RTRW Kabupaten Probolinggo 2010-2029. Mainland atau agropolis di kawasan Barat adalah Kecamatan Sukapura, khususnya di desa Sukapura, sedangkan kecamatan lainnya sebagai hinterland atau pendukung. Agropolis di kawasan Timur adalah Kecamatan Krucil, khususnya di desa Krucil, sedangkan kecamatan lainnya sebagai hinterland.

Komoditi unggulan di kawasan agropolitan yang menjadi prioritas adalah: kopi, durian, alpukat dan manggis, mangga, pisang, kentang, kubis, bawang daun, wortel, cabe merah, jagung, susu sapi, sapi potong, kapuk randu dan madu.
\end{abstract}

\section{Kata kunci : Agropolitan, Kawasan, Hinterland .}

\section{PENDAHULUAN}

\section{Latar Belakang}

Agropolitan merupakan konsep pembangunan tata ruang yang ditujukan agar dapat mendorong kegiatan perekonomian suatu kawasan yang berbasis pertanian sehingga system agribisnis yang berada di wilayah tersebut bias berjalan dengan baik. Secara struktur, suatu kawasan agropolitan terdiri dari kawasan sentra-sentra produksi atau hinterland dan pusat agribisnis yaitu kota tani atau mainland. Untuk mewujudkan suatu kawasan menjadi kawasan agropolitan yang mandiri diperlukan suatu konsep perencanaan yang terstruktur dan berkelanjutan.

Pemerintah Kabupaten Probolinggo telah menetapkan tujuh kecamatan di wilayahnya sebagai wilayah agropolitan yakni Kecamatan Tiris, Krucil, Gading, Tongas, Lumbang, Sukapura dan Sumber. Ketujuh kecamatan tersebut dibagi dua wilayah yakni daerah timur meliputi Kecamatan Tiris, Krucil, dan Gading. Sedangkan wilayah barat meliputi Kecamatan Tongas, Lumbang, Sukapura dan Sumber.

\section{Rumusan Masalah}

Rumusan masalah dari Penyusunan Masterplan Pengembangan Kawasan Agropolitan Kabupaten Probolinggo 2017-2026, sebagai berikut: 
1. Bagaimanaperkembangan dan perubahan kondisi eksisting Kawasan Agropolitan Kabupaten Probolinggo, yang telah ditetapkan dalam dokumen masterplan periode sebelumnya (2006-2016)?

2. Bagaimana perkembangan potensi dan realitas sentra-sentra produksi di Kawasan Agropolitan Kabupaten Probolinggo?

3. Bagaimana kebutuhan sarana dan prasarana pengembangan Kawasan Agropolitan Kabupaten Probolinggo selama 10 tahun yang akan datang (2017-2026).

4. Belum adanya prioritas lokasi program dan kegiatan spesifik di tingkat desa di semua kecamatan kawasan agropolitan Kabupaten Probolinggo dalam masterplan periode se sebelumnya (2006-2016).

5. Belum adanya rencana aksi yang memuat indikasi program dan kegiatan yang mendukung pengembangan kawasan agropolitan dalam jangka menengah (10 tahun) yaitu tahun 2017-2026.

\section{Maksud dan Tujuan}

Maksud dari pelaksanaan kegiatan Penyusunan Masterplan Pengembangan Kawasan Agropolitan Kabupaten Probolinggo 2017-2026 adalah menyediakan bahan rujukan dan kerangka dasar perencanaan dalam pengembangan kawasan agropolitan sekaligus untuk memberikan arahan yang jelas dan sinergis bagi para pemangku kepentingan.

Tujuan dilaksanakannya kegiatan ini adalahmelakukan review terhadap Masterplan Pengembangan Kawasan Agropolitan Kabupaten Probolinggo 2006-2016 yang akan berakhir dan perlu koreksi untuk disesuaikan dengan kondisi eksisting dan dilanjutkan agar pengembangan kawasan agropolitan bisa lebih terarah dan terkoordinasi yang membidangi serta memberikan dampak bagi pertumbuhan ekonomi.

\section{PROFIL KAWASAN AGROPOLITAN Sistem Produksi di Kawasan Agropolitan}

Produk unggulan di kawasan agropolitan merupakan komoditas yang bisa menimbulkan multiplier effect bagi sekitarnya. Adapun komoditas pada kawasan timur adalah Jagung, Manggis, Durian, Kubis, Alpukat, Tebu dan Jeruk Besar. Adapun komoditas unggulan di kawasan barat adalah Mangga, Jagung, Kapuk randu, Kentang, Kubis, Bawang daun, Kambing, Strawberry, Kentang Merah dan Durian Merah.

\section{Sistem Pasar di Kawasan Agropolitan}

Sistem pasar dalam kawasan agropolitan Kabupaten Probolinggo belum terbentuk secara penuh. Berbagai komoditi unggulan dijual dan dipasarkan langsung ke pasarpasar di daerah lain, seperti Lumajang, Jember, Surabaya dan Jakarta. Kawasan agropolitan Kabupaten Probolinggo belum memiliki pasar induk untuk komoditi pertanian, yang mampu menampung dan memfasilitasi terjadinya aktifitas perdagangan hasil panen petani. Komoditi buah-buahan banyak diperdagangkan di pasar-pasar besar di kabupaten lain yang berbatasan dengan Kabupaten Probolinggo.

Tidak adanya pasar khusus bagi hasil pertanian akan membuat informasi pasar hanya satu arah dari pedagang ke petani. Petani tidak memiliki akses menuju pasar secara langsung dan membuat kekuatan tawar menawar (bargaining) dengan pedagang menjadi sangat lemah. Bahkan masih ada komoditi yang dibeli pedagang dengan harga 
yang tidak transparan bagi petani. Hal ini merugikan dalam jangka panjang karena tidak akan mendorong petani untuk meningkatkan produktivitas usahataninya.

Sebagian besar hasil pertanian dari kawasan agropolitan Kabupaten Probolinggo dijual ke pedagang pengumpul di tingkat desa dalam keadaan segar. Kegiatan agroindustry atau pengolahan hasil pertanian belum banyak dilakukan oleh rumah tangga petani. Para pedagang tentu tidak dapat diharapkan mendorong tumbuhnya industry kecil pengolahan tersebut. Adalah tugas pemerintah daerah melalui PD untuk mendorong terjadinya peningkatan nilai tambah produk pertanian melalui pengolahan.

Beberapa komoditi di kawasan agropolitan yang memiliki potensi pasar yang luas dalam bentuk olahan antara lain: kopi, alpukat, durian, jagung, kentang dan tanaman rempah-rempah. Salah satu produk andalan dari kawasan agropolitan Sukapura yang disukai masyarakat adalah minuman pokak. Namun demikian skala usahanya masih rumah tangga dan masih sulit untuk memperluas pasarnya.

Komoditi unggulan kawasan agropolitan yang perlu diolah adalah madu lebah dari Kecamatan Lumbang. Peningkatan produksi madu dari tahun ke tahun menunjukkan bahwa masyarakat di lokasi tersebut telah memahami teknis budidaya madu dari lebah yang diternakkan. Sehingga produksi madu telah dirasakan manfaatnya dalam meningkatkan pendapatan keluarga petani. Permasalahan yang dihadapi oleh para peternak lebah adalah mulai berkurangnya persediaan tanaman yang menghasilkan pakan untuk koloni lebah (bunga tanaman/pohon). Sehingga banyak peternak lebah harus membawa koloni lebahnya ke daerah lain di luar Kecamatan Lumbang. Pada kondisi keterbatasan pakan lebah, maka peternak lebah menjadi penggembala lebah madu. Pada umumnya produksi madu akan ditampung dan dikumpulkan oleh tengkulak dalam kondisi segar. Madu tersebut dibawa ke kota Surabaya dan Jakarta untuk diolah dan dikemas menjadi madu olahan yang lebih mahal dan bervariasi. Hal ini menjadi kewenangan dari PD yang membidangi Perkebunan dan Kehutanan untuk membina dan memberikan pelatihan teknologi pengolahan madu.

Sistem pasar bagi kawasan agropolitan Kabupaten Probolinggo harus terbagi menjadi pasar wilayah Timur dan Barat. Karena kedua wilayah tersebut terpisah oleh beberapa kecamatan dan berjarak cukup jauh. Pasar penampung hasil pertanian dapat dibangun dengan dua cara. Pertama, dengan memanfaatkan pasar desa atau pasar kecamatan yang sudah ada dan berukuran cukup besar. Kedua, membangun pasar baru pada desa yang ditentukan terlebih dahulu melalui studi kelayakan pembangunan pasar tani. Pasar tani wilayah Timur berfungsi menampung produksi pertanian dari Kecamatan Gading, Krucil dan Tiris. Sedangkan pasar tani wilayah Barat berfungsi menampung produksi dari Kecamatan Sumber, Sukapura, Lumbang dan Tongas. Pasar tani perlu dibangun agar terjadi keseimbangan antara permintaan dan penawaran produksi pertanian. Melalui mekanisme pasar tani dapat diketahui informasi harga komoditi setiap minggu atau bulan secara teratur dan terbuka bagi kelompok petani. Sehingga tersedia pilihan tujuan pasar atau pedagang yang menawarkan harga terbaik. Hal lain yang menjadi perhatian kelembagaan pasar tersebut. Pasar tersebut harus dikelola secara tersendiri sebagai pasar tani. Pasar tani bukan hanya tanggungjawab dari PD yang membidangi Perindustrian Perdagangan, namun juga melibatkan kegiatan dari PD yang membidangi Pertanian, dan PD terkait lainnya.

\section{METODOLOGI}


Metode yang digunakan dalam penelitian ini adalah metode analisis SWOT (Streght, Weakness, Opportunity, Thread) digunakan untuk mengetahui kekuatan, kelemahan, peluang dan ancaman yang dihadapi dalam pengembangan kawasan agropolitan di Kabupaten Probolinggo.

\section{HASIL ANALISIS DAN PEMBAHASAN Analisis SWOT Kawasan Agropolitan}

Analisis SWOT (Streght, Weakness, Opportunity, Thread) digunakan untuk mengetahui kekuatan, kelemahan, peluang dan ancaman yang dihadapi dalam pengembangan kawasan agropolitan di Kabupaten Probolinggo. Analisis dilakukan secara kuantitatif untuk mendapatkan alternatif strategi pengembangan kawasan di setiap kecamatan.

Tabel 1.

Analisis SWOT Kawasan Agropolitan Kabupaten Probolinggo, 2016

\begin{tabular}{|c|c|c|c|c|}
\hline No. & Faktor-faktor Internal & Bobot & Rating & Skor \\
\hline & Kekuatan (strength) & & & \\
\hline 1. & $\begin{array}{l}\text { Sumberdaya alam pertanian yang melimpah, khususnya hortikultura } \\
\text { sayuran, buah-buahan, perkebunan, dan madu }\end{array}$ & 0,08 & 4 & 0,32 \\
\hline 2. & Sumberdaya alam peternakan, khususnya sapi perah dan sapi potong & 0,08 & 4 & 0,32 \\
\hline 3. & Pertumbuhan penduduk di kawasan agropolitan meningkat setiap tahun & 0,05 & 3 & 0,15 \\
\hline 4. & $\begin{array}{l}\text { Adanya tujuan ekowisata yang potensial dan telah dikenal oleh masyarakat } \\
\text { luas }\end{array}$ & 0,08 & 3 & 0,24 \\
\hline 5. & $\begin{array}{l}\text { Adanya dukungan pemerintah daerah dan provinsi dalam regulasi dan } \\
\text { anggaran kegiatan di kawasan agropolitan }\end{array}$ & 0,06 & 3 & 0,18 \\
\hline 6. & $\begin{array}{l}\text { Tersedianya kelembagaan pendukung pertanian dan peternakan (BPP, kios } \\
\text { saprodi, koperasi, perbankan dan pasar desa) }\end{array}$ & 0,10 & 2 & 0,20 \\
\hline \multirow[t]{3}{*}{7.} & $\begin{array}{l}\text { Adanya kerjasama/kemitraan usaha antara perusahaan swasta dan } \\
\text { masyarakat (jamur, mangga, susu sapi, dan ekowisata) }\end{array}$ & 0,08 & 2 & 0,16 \\
\hline & Sub Total & $\mathbf{0 , 5 3}$ & & 1,57 \\
\hline & Kelemahan (weakness) & & & \\
\hline 1. & Infrastruktur jalan dan komunikasi perlu peningkatan dan percepatan & 0,08 & 4 & 0,32 \\
\hline 2. & $\begin{array}{l}\text { Kelembagaan pendukung pertanian masih kurang, khususnya lembaga } \\
\text { keuangan dan pemasaran }\end{array}$ & 0,06 & 3 & 0,18 \\
\hline 3. & $\begin{array}{l}\text { Belum adanya pasar khusus hasil pertanian (pasar tani) di kawasan } \\
\text { agropolitan }\end{array}$ & 0,08 & 3 & 0,24 \\
\hline 4. & $\begin{array}{l}\text { Produk olahan hasil pertanian di setiap kecamatan masih mengalami banyak } \\
\text { kendala/hambatan pengembangan }\end{array}$ & 0,05 & 3 & 0,18 \\
\hline 5. & $\begin{array}{l}\text { Adanya keterbatasan air dan penggunaan pestisida berlebihan untuk } \\
\text { budidaya sayuran }\end{array}$ & 0,04 & 2 & 0,08 \\
\hline 6. & Kualitas SDMpetani/peternak masih perlu ditingkatkan & 0,04 & 2 & 0,10 \\
\hline 7. & $\begin{array}{l}\text { Penerapan teknologi udidaya tanaman dan peternakan masih perlu } \\
\text { ditingkatkan }\end{array}$ & 0.04 & 2 & 0,10 \\
\hline 8. & $\begin{array}{l}\text { Kelompok tani/gapoktan kurang aktif dalam mengatasi masalah usaha } \\
\text { secara kelompok }\end{array}$ & 0,04 & 2 & 0,08 \\
\hline \multirow[t]{4}{*}{9.} & $\begin{array}{l}\text { Keterbatasan hijauan pakan ternak untuk sapi perah, pohon randu untuk } \\
\text { lebah madu, }\end{array}$ & 0,04 & 3 & 0,12 \\
\hline & Sub Total & 0,47 & & 1,40 \\
\hline & Total & 1,00 & & 2,97 \\
\hline & Skor Kekuatan - Skor Kelemahan & & Plus & 0,17 \\
\hline
\end{tabular}

\begin{tabular}{|c|l|c|c|c|}
\hline No. & \multicolumn{1}{|c|}{ Faktor-faktor Eksternal } & Bobot & Rating & Skor \\
\hline & Peluang (Opportunity) & & & \\
\hline 1. & $\begin{array}{l}\text { Permintaan pasar produk pertanian terus meningkat untuk pasar domestik } \\
\text { dan ekspor }\end{array}$ & 0,15 & 4 & 0,60 \\
\hline
\end{tabular}


Penyusunan Masterplan Pengembangan Kawasan Agropolitan Kabupaten Probolinggo Tahun 2017 (Markus Patiung)

\begin{tabular}{|c|l|c|c|c|}
\hline No. & \multicolumn{1}{|c|}{ Faktor-faktor Eksternal } & Bobot & Rating & Skor \\
\hline 2. & Permintaan produk olahan hasil pertanian untuk pasar kota besar meningkat & 0,10 & 3 & 0,30 \\
\hline 3. & $\begin{array}{l}\text { Adanya kemajuan teknologi informasi, komunikasi dan pengolahan hasil } \\
\text { pertanian untuk mendukung pemasaran }\end{array}$ & 0,10 & 2 & 0,20 \\
\hline 4. & $\begin{array}{l}\text { Terbukanya kerjasama kemitraan produksi dan pemasaran dengan } \\
\text { perusahaan swasta }\end{array}$ & 0,10 & 3 & 0,30 \\
\hline 5. & Meningkatnya kunjungan wisatawan untuk ekowisata dan agrowisata & 0,10 & 3 & 0,30 \\
\hline 6. & Meningkatnya permintaan produk pertanian organik / ramah lingkungan & 0,05 & 2 & 0,10 \\
\hline & Sub Total & 0,65 & & 1,80 \\
\hline & Ancaman (Thread) & & \\
\hline 1. & $\begin{array}{l}\text { Persaingan produk pertanian dari daerah lain, terutama dalam kualitas dan } \\
\text { tingkat produktivitas }\end{array}$ & 0,10 & 4 & 0,40 \\
\hline 2. & $\begin{array}{l}\text { Pesatnya perkembangan produk olahan dari luar kabupatan dan produk } \\
\text { impor }\end{array}$ & 0,10 & 3 & 0,30 \\
\hline 3. & $\begin{array}{l}\text { Adanya permintaan pasar untuk produk olahan pertanian yg berstandar dan } \\
\text { ramah lingkungan }\end{array}$ & 0,10 & 2 & 0,20 \\
\hline 4. & Persaingan dalam pemasaran tujuan ekowisata dan agrowisata & 0,05 & 2 & 0,10 \\
\hline & Sub Total & 0,35 & & 1,00 \\
\hline & Total & 1,00 & & 2,80 \\
\hline & Skor Peluang - Skor Ancaman & Plus & 0,80 \\
\hline
\end{tabular}

Kawasan Agropolitan Kabupaten Probolinggo secara keseluruhan berada pada kuadran satu (I) artinya berada di kuadran pertumbuhan. Strategi yang diutamakan adalah dengan mengoptimalkan kekuatan yang dimiliki untuk memanfaatkan peluang yang tersedia. Namun demikian masih banyak kelemahan yang dijumpai di kawasan ini sehingga system agropolitan belum berjalan dengan baik.

Strategi pengembangan kawasan agropolitan Kabupaten Probolinggo harus mengacu pada peningkatan kinerja system agribisnis yang ada. Terdapat 4 bidang fokus strategi, yaitu:

\section{Fokus Sumberdaya Manusia Petani.}

Strategi ini mengutamakan upaya peningkatan kualitas SDM petani baik secara individu maupun berkelompok. Yaitu melalui kegiatan penyuluhan pertanian, pelatihan dan kegiatan peningkatan letrampilan agribisnis lainnya. Materi dan cara penyuluhan dan pelatihan sebaiknya disampaikan dalam bahasa yang sederhana dan praktis, mengingat latar belakang pendidikan petani yang masih rendah.

\section{Fokus Peningkatan Produktivitas Usahatani Persatuan Luas}

Strategi ini mengutamakan upaya peningkatan produksi komoditi persatuan luas dengan prinsip praktik agribisnis yang baik (Good Agribusiness Practice) dan bagian dari pertanian berkelanjutan (sustainable farming).

\section{Fokus Peningkatan Nilai Tambah Hasil Panen}

Strategi ini mengutamakan upaya teknologi pengolahan pasca panen dan pemasaran yang lebih efisien. Prinsipnya adalah meningkatkan pendapatan keluarga petani dengan cara mengolah komoditi segar menjadi produk olahan yang bernilai lebih tinggi di pasar atau menjual ke pasar yang lebih jauh.

\section{Fokus Peningkatan Peran PD dan Lembaga Penunjang Pertanian}


Strategi ini mengutamakan penyusunan program dan kegiatan yang tepat dari setiap PD yang membidangi / Badan yang terkait secara structural maupun fungsional dalam pengembangan kawasan agropolitan di Kabupaten Probolinggo. Diharapkan kegiatan yang dilakukan pemerintah daerah melalui PD mampu dilakukan dengan pendekatan lintas sektoral dan berkelanjutan.

\section{RENCANA PENGEMBANGAN KAWASAN AGROPOLITAN Rencana Tata Ruang dan Kependudukan}

Pengembangan Kawasan Agropolitan (PKA) Kabupaten Probolinggo dilaksanakan mengikuti Rencana Tata Ruang Wilayah (RTRW) Kabupaten Probolinggo Tahun 2010-2029 yang ditetapkan melalui Peraturan Daerah Nomor 03 Tahun 2011. Sehingga keberadaan PKA sesuai dengan penataan struktur dan pola ruang yang telah direncanakan oleh Pemerintah Kabupaten Probolinggo.

Berdasarkan perda tersebut, Kawasan Agropolitan, adalah kawasan yang meliputi satu atau lebih pusat kegiatan pada wilayah perdesaan sebagai sistem produksi pertanian dan pengelolaan sumber daya alam tertentu yang ditunjukkan oleh adanya keterkaitan fungsional dan hierarki keruangan satuan sistem permukiman dan sistem agrobisnis. Berdasarkan pola ruangnya, kawasan agropolitan merupakan salah satu dari beberapa Kawasan Strategis Kabupaten (KSK) yaitu wilayah yang penataan ruangnya diprioritaskan karena mempunyai pengaruh sangat penting dalam lingkup Kabupaten terhadap ekonomi, sosial, budaya dan/atau lingkungan. Selain itu, berdasarkan lokasinya, dalam struktur tata ruang, kawasan agropolitan merupakan Kawasan Perdesaan, yaitu wilayah yang mempunyai kegiatan utama pertanian termasuk pengelolaan sumberdaya alam dengan susunan fungsi kawasan sebagai tempat permukiman perdesaan, pelayanan jasa pemerintahan, pelayanan sosial dan kegiatan ekonomi. Penataan ruang wilayah bagi kawasan agropolitan Kabupaten Probolinggo ditetapkan sebagai berikut:

\section{Visi, Misi dan Tujuan Penataan Ruang Wilayah}

Visi penataan ruang wilayah daerah adalah terwujudnya ruang wilayah Kabupaten Probolinggo sebagai sentra pertanian unggulan. Hal ini sangat sesuai dan terkait erat dengan maksud dan tujuan pengembangan kawasan agropolitan Kabupaten Probolinggo. Visi tersebut dicapai melalui beberapa misi, meliputi:

a. mewujudkan penyediaan lahan dalam peningkatan kegiatan produk utama dan unggulan,

b. mewujudkan pengembangan pusat kegiatan pertanian sebagai sentra produk unggulan,

c. mewujudkan penyediaan sarana dan prasarana pertanian berbasis pengembangan prasarana wilayah,

d. mewujudkan pengembangan dan peluang investasi produktif berbasis pertanian,

e. mewujudkan daya saing daerah melalui pengembangan pertanian yang didukung oleh industri dan ekowisata yang ramah lingkungan.

Tujuan Penataan Ruang Kabupaten Probolinggo adalah mewujudkan Kabupaten Probolinggo sebagai sentra komoditas pertanian yang berdaya saing di tingkat JawaBali dengan mengembangkan agropolitan di Bagian Barat dan di Bagian Timur serta minapolitan di bagian Utara dan Tengah yang didukung oleh industri dan ekowisata. 


\section{Kebijakan Penataan Ruang Wilayah}

Pencapaian tujuan tersebut dilaksanakan melalui penetapan kebijakan yang mendukung atau terkait dengan kawasan agropolitan, meliputi:

a. Pemantapan sistem agropolitan untuk peningkatan komoditi pertanian unggulan disertai pengelolaan hasil dan peningkatan peran dalam ekowisata. Strateginya meliputi mengembangkan kawasan sesuai potensinya yang dihubungkan dengan pusat kegiatan mendukung agropolitan, dan mengembangkan kawasan agropolitan untuk mendorong pertumbuhan kawasan perdesaan di wilayah Probolinggo Timur yang meliputi Kecamatan Gading, Krucil, dan Tiris dan Probolinggo Barat yang meliputi Kecamatan Tongas, Kecamatan Lumbang, Sukapura, dan Sumber.

b. Pengembangan pusat-pusat pelayanan secara berhirarki dan bersinergis antara pusat pengembangan utama di ibukota kabupaten dan perkotaan lainnya serta pengembangan sistem permukiman perdesaan berbasis agropolitan. Strateginya meliputi menetapkan hierarki simpul pertumbuhan ekonomi wilayah terutama yang berfungsi sebagai pusat agropolitan, industri dan ekowisata, memantapkan fungsi simpul-simpul wilayah dan memantapan keterkaitan antar simpul wilayah dan interaksi antara simpul wilayah dengan kawasan perdesaan sebagai hinterland-nya.

c. Pendistribusian persebaran penduduk sesuai dengan kebijakan pusat-pusat pelayanan. Strateginya meliputi mendistribusikan persebaran penduduk dengan pengembangan sarana-prasarana dan pada kawasan pusat pertumbuhan baru dan memeratakan persebaran penduduk dengan perbaikan sarana-prasarana dan infrastruktur di kawasan perdesaan atau kawasan kurang berkembang guna mengurangi urbanisasi.

d. Pengembangan kelengkapan prasarana wilayah dan prasarana lingkungan dalam mendukung pengembangan sentra produksi pertanian, industri, ekowisata dan pusat permukiman secara terpadu dan efisien. Strateginya meliputi: mengembangkan sistem transportasi secara intermoda sampai ke pusat produksi pertanian, industri dan pelayanan pariwisata, meningkatkan jaringan energi dan pelayanan secara interkoneksi jawa-bali dan pelayanan sampai pelosok, mendayagunakan sumber daya air dan pemeliharaan jaringan untuk pemenuhan kebutuhan air baku dan sarana dan prasarana pengairan kawasan pertanian, meningkatkan jumlah, mutu dan jangkauan pelayanan komunikasi serta kemudahan mendapatkannya diprioritaskan mendukung pengembangan pertanian, pariwisata dan industri.

e. Pengembangan kawasan budidaya mendukung pemantapan sistem agropolitan serta industri berbasis pertanian dan ekowisata. Strateginya meliputi mengembangkan hutan produksi guna meningkatkan produktivitas lahan dengan memperhatikan keseimbangan lingkungan, menetapkan dan mengembangkan kawasan hutan rakyat, mengamankan lahan pertanian berkelanjutan dan menjaga suplai pangan nasional, mengembangkan komoditas unggul perkebunan di setiap wilayah dan meningkatkan pengembangan pariwisata berbasis ekowisata dengan tetap memperhatikan kelestarian lingkungan, pelestarian budaya leluhur dan melibatkan peran serta masyarakat.

\section{Rencana Struktur Ruang Kawasan Agropolitan}

Struktur ruang wilayah kabupaten meliputi sistem pusat pelayanan dan sistem jaringan prasarana wilayah kabupaten. Sistem pusat pelayanan terdiri dari sistem perkotaan dan sistem perdesaan. Kawasan agropolitan merupakan gabungan dari sistem 
perkotaan dan perdesaan. Sistem perkotaan yang terkait dengan kawasan agropolitan meliputi:

1. Pusat-pusat perkotaan dan wilayah pelayanan.

2. Rencana fungsi pusat pelayanan.

3. Pengembangan fasilitas kawasan perkotaan.

4. Sistem perdesaan dilakukan dengan membentuk pusat pelayanan desa berupa Pusat Pelayanan Lingkungan (PPL) yang dihubungkan dengan sistem jaringan jalan dan infrastruktur yang dibutuhkan untuk pengembangan pedesaan.

5. Sistem jaringan prasarana wilayah kabupaten dibentuk oleh sistem jaringan prasarana utama dan dilengkapi dengan sistem jaringan prasarana lainnya sesuai dengan peraturan perundang-undangan.

6. Jaringan jalan yang penting bagi pengembangan kawasan agropolitan adalah rencana jalan kabupaten.

7. Rencana prasarana lalu lintas dan angkutan jalan yang mendukung kawasan agropolitan adalah pengembangan terminal penumpang dan terminal barang.

8. Rencana sistem jaringan prasarana sumber daya air untuk kawasan agropolitan.

9. Rencana sistem jaringan irigasi.

10. Sistem jaringan prasarana telekomunikasi.

11. Rencana sistem jaringan prasarana lingkungan.

\section{Rencana Pola Ruang Kawasan Agropolitan}

Rencana pola ruang adalah rencana distribusi peruntukan ruang dalam wilayah kabupaten yang meliputi kawasan lindung dan kawasan budidaya.

Pola ruang untuk kawasan lindung, meliputi:

a. kawasan hutan lindung.

b. kawasan yang memberikan perlindungan terhadap kawasan bawahannya.

c. kawasan perlindungan setempat.

d. kawasan suaka alam, pelestarian alam dan cagar budaya.

e. kawasan rawan bencana alam.

f. kawasan lindung geologi dan kawasan lindung lainnya.

Pola Ruang Kawasan Budidaya, meliputi:

Pola ruang untuk kawasan budidaya terdiri dari:

a. kawasan peruntukan hutan produksi.

b. kawasan hutan rakyat.

c. kawasan peruntukan pertanian meliputi kawasan peruntukan pertanian tanaman pangan, hortikultura, perkebunan dan peternakan..

d. Lahan pertanian pangan berkelanjutan.

e. kawasan peruntukan industri agropolitan hanya industri kecil dan rumah tangga.

f. kawasan peruntukan pariwisata, meliputi: kawasan wisata alam, kawasan budaya; dan kawasan wisata buatan.

g. kawasan peruntukan permukiman meliputi permukiman perkotaan dan permukiman perdesaan.

Sebagai sebuah kawasan, kawasan agropolitan adalah bagian dari kawasan strategis ekonomi. Kawasan strategis ekonomi berdasarkan Kawasan Strategis Propinsi (KSP), meliputi: kawasan agropolitan regional yang merupakan sistem agropolitan 
Bromo - Tengger- Semeru; dan kawasan agropolitan Kabupaten Probolinggo. Kawasan strategis ekonomi meliputi: a) kawasan andalan, b) kawasan agropolitan, c) kawasan minapolitan, d) kawasan pertambangan, e) kawasan industri; dan f) kawasan pariwisata. Kawasan agropolitan Kabupaten Probolinggo terdiri dari 2 wilayah pengembangan, meliputi:

- wilayah pengembangan barat, terletak di Kecamatan Sukapura, Kecamatan Sumber, Kecamatan Lumbang, dan Kecamatan Tongas dengan pusat di Perkotaan Tongas;

- wilayah pengembangan bagian timur, terletak di Kecamatan Tiris, Kecamatan Krucil dan Kecamatan Gading dengan pusat di Perkotaan Gading.

\section{Rencana Zonasi Komoditi Unggulan}

Setelah mengetahui lokasi pengembangan kawasan agropolitan Kabupaten Probolinggo berdasarkan tata ruang wilayahnya, maka diperlukan rencana zonasi komoditi unggulan yang akan dikembangkan di lokasi tersebut. Lokasi kawasan agropolitan wilayah Barat dan Timur menjawab dimana lokasi program berada, sedangkan zonasi komoditi unggulan menjawab target pengembangan komoditi pertanian.

Penetapan zonasi terbagi dua, meliputi zonasi wilayah atau sentra produksi komoditi dan zonasi komoditi yang diunggulkan secara ekonomi dan berdaya saing. Zonasi wilayah menggambarkan kondisi eksisting usahatani yang telah ada saat ini, dan zonasi komoditi menggambarkan peluang pengembangan komoditi dalam jangka panjang, atau 10 tahun ke depan.

\section{Rencana Pengembangan Agribisnis}

Visi dari Pengembangan Kawasan Agropolitan adalah : "Tercapainya peningkatan kesejahteraan masyarakat melalui pengembangan sistem agribisnis yang terpadu bagi komoditi pertanian unggulan di kawasan agropolitan Kabupaten Probolinggo". Peningkatan kesejahteraan petani dan keluarga adalah kata kuncinya.

Adapun misi yang diperlukan untuk mewujudkan visi tersebut, meliputi:

1. Meningkatkan ketersediaan sarana produksi untuk pengembangan produk unggulan, meliputi bibit, pupuk, biopestisida, hijauan dan konsentrat pakan ternak, dan alsintan.

2. Meningkatkan ketrampilan budidaya tanaman dan peternakan untuk meningkatkan produktivitas usahatani, sesuai panduan praktik pertanian yang baik.

3. Meningkatkan penerapan teknologi pasca panen yang lebih baik untuk mengurangi kehilangan hasil dan meningkatkan penerimaan usahatani.

4. Meningkatkan pemasaran hasil panen melalui penyediaan sarana dan prasarana pemasaran yang lebih baik (pasar, teknologi sortasi, grading dan kemasan, dan penyediaan informasi pasar yang baik).

5. Meningkatkan nilai tambah komoditi melalui penerapan pengolahan komoditi menjadi produk setengah jadi atau produk jadi (siap konsumsi).

6. Meningkatkan kualitas kelembagaan pendukung pertanian, meliputi penyuluhan, kelompoktani dan gapoktan, koperasi tani/KUD, dan lembaga keuangan perdesaan (bank/non bank)

7. Meningkatkan pemahaman dan pelaksanaan manajemen rantai pasok (supply chain management) komoditi bagi kelompoktani dan koperasi tani melalui pengembangan dan perluasan kemitraan agribisnis. 
8. Meningkatkan keterpaduan program dan kegiatan PD dan lintas sektoral sebagai wujud komitmen pemerintah daerah dalam peningkatan kesejahteraan petani di kawasan agropolitan.

9. Meningkatkan kualitas lingkungan hidup pertanian terutama kualitas lahan, ketersediaan air dan menekan penggunaan pestisida untuk buah dan sayuran unggulan.

Penjabaran misi-misi tersebut diatas dalam arah kebijakan, strategi dan sasaran yang akan dicapai dirangkum sebagai berikut:

\section{Rencana Program Prioritas Desa Kawasan Agropolitan}

Program pengembangan kawasan agropolitan mencakup banyak aspek dan wilayah kerja yang relative luas, yaitu sebanyak 7 kecamatan yang terbagi dalam dua wilayah, yaitu wilayah Barat dan Timur. Untuk itu dibutuhkan pentahapan pelaksanaan selama 10 tahun (2017-2026) dan prioritas lokasi desa yang dibangun terlebih dahulu. Desa yang dibangun paling awal, dapat diharapkan sebagai desa contoh yang mampu menarik, menghela dan mendorong desa-desa lain untuk tumbuh di periode berikutnya. Desa-desa prioritas diharapkan menjadi perintis terbangunnya agropolis yang sebenarnya, yaitu desa pertanian yang menjadi sentra produksi komoditi yang unggul dan berdaya saing.

\section{Rencana Pengembangan Fasum dan Jaringan Utilitas}

Pembangunan fasilitas umum tersebut membutuhkan biaya pembangunan yang cukup besar karena berukuran cukup layak untuk menunjang kegiatan agribisnis di beberapa kecamatan. Fasilitas umum tersebut meliputi:

1. Pembangunan pasar tani di desa Krucil, Kecamatan Krucil yang berfungsi sebagai pasar transit komoditi pertanian maupun agroindustri dari 3 kecamatan yaitu Krucil, Tiris dan Gading.

2. Pembangunan pasar tani di desa Sapikerep, Kecamatan Sukapura atau desa Lumbang Kecamatan Lumbang yang berfungsi sebagai pasar transit komoditi pertanian dan agroindustri dari 3 kecamatan yaitu Sukapura, Sumber dan Lumbang.

3. Pembangunan subterminal agribisnis untuk kawasan Barat di desa Tongas Kulon atau Tongas Wetan di Kecamatan Tongas, yang berlokasi dekat dengan jalan arteri, namun tidak ditepi jalan raya Surabaya-Situbondo.

4. Pembangunan subterminal agribisnis untuk kawasan Timur di desa Condong di Kecamatan Gading.

5. Pergudangan komoditi yang modern di setiap subterminal agribisnis.

6. Pembangunan kantor pusat subterminal agribisnis di Kecamatan Tongas yang mengendalikan manajemen seluruh kawasan agropolitan.

\section{Rencana Pengembangan Pariwisata Kawasan Agropolitan}

Pengembangan pariwisata sangat erat kaitannya dengan pengembangan kawasan agropolitan, karena lokasi obyek pariwisata tersebut bersinggungan dan menyatu di beberapa lokasi agropolitan. Bahkan kegiatan agribisnis juga dijadikan salah satu upaya dan destinasi pengembangan pariwisata, seperti wisata petik strawberry di desa Jetak Kecamatan Sukapura, dan wisata petik durian di desa Waturiti, Kecamatan Lumbang. 
Pengembangan wisata alam di kawasan agropolitan timur membutuhkan lebih banyak dukungan infrastruktur, seperti penyediaan akomodasi/penginapan, warung makan, dan pasar wisata (rest area) yang memadai. Terutama di kecamatan Tiris dan Krucil, yang memiliki potensi destinasi wisata alam yang prospektif dikembangkan.

\section{PROGRAM PENGEMBANGAN KAWASAN AGROPOLITAN}

Pengembangan kawasan agropolitan bukan hanya urusan PD yang membidangi pertanian, PD yang membidangi Peternakan, Perkebunan dan Kehutanan saja. Sebagai program pembangunan dengan pendekatan kawasan maka berbagai PD yang memiliki program dalam kawasan agropolitan tersebut, dapat dikategorikan sebagai pendukung atau memiliki kontribusi dalam pengembangan kawasan.

Penyusunan matriks indikasi program tersebut didasarkan atas Peraturan Menteri Dalam Negeri Nomor 13 Tahun 2006 tentang Pedoman Pengelolaan Keuangan Daerah. Periode pertama dalam mariks ini berlangsung selama 5 tahun, yaitu mulai tahun 2017 sampai dengan tahun 2021. Periode ke dua, berlangsung selama 5 tahun berikutnya yaitu mulai tahun 2022 sampai dengan tahun 2026. Periode pertama (2017-2021) menekankan dan memberikan prioritas pada pembangunan infrastruktur dan peningkatan sistem agribisnis di kawasan agropolitan. Sedangkan pada periode kedua (2022-2026) memberikan prioritas pada peningkatan kualitas SDM dan optimalisasi manajemen rantai pasok produk unggulan dari kawasan agropolitan. Diharapkan dalam 5 tahun pertama, permasalahan infrastruktur kawasan telah diatasi sehingga dapat beralih menuju strategi pengembangan SDM dan manajemen agribisnis.

\section{KESIMPULAN DAN REKOMENDASI Kesimpulan}

Berdasarkan hasil kajian penyusunan Masterplan Pengembangan Kawasan Agropolitan tersebut diatas, dapat disusun beberapa kesimpulan, sebagai berikut:

\section{Kawasan Agropolitan Kabupaten Probolinggo}

Kawasan agropolitan Kabupaten Probolinggo terdiri dari 7 kecamatan, yaitu Kecamatan Krucil, Tiris dan Gading (Kawasan Agropolitan Timur) dan Kecamatan Sukapura, Sumber, Lumbang dan Tongas (Kawasan Agropolitan Barat). Kawasan ini sesuai dengan RTRW Kabupaten Probolinggo 2010-2029. Mainland atau agropolis di kawasan Barat adalah Kecamatan Sukapura, khususnya di desa Sukapura, sedangkan kecamatan lainnya sebagai hinterland atau pendukung. Agropolis di kawasan Timur adalah Kecamatan Krucil, khususnya di desa Krucil, sedangkan kecamatan lainnya sebagai hinterland.

\section{Komoditi Unggulan di Kawasan Agropolitan}

Komoditi unggulan di kawasan agropolitan yang menjadi prioritas adalah: kopi, durian, alpukat dan manggis, mangga, pisang, kentang, kubis, bawang daun, wortel, cabe merah, jagung, susu sapi, sapi potong, kapuk randu dan madu.

\section{Desa-desa Prioritas di Kawasan Agropolitan}

Pengembangan kawasan agropolitan Kabupaten Probolinggo diprioritaskan dan difokuskan pada desa-desa berikut ini:

a. Kecamatan Krucil : Desa Krucil dan Bremi;

b. Kecamatan Tiris : Desa Andungbiru dan Ranugedang;

c. Kecamatan Gading : Desa Condong dan Mojolegi; 
d. Kecamatan Sukapura : Desa Ngadisari dan Sukapura;

e. Kecamatan Sumber : Desa Ledokombo dan Pandansari;

f. Kecamatan Lumbang : Desa Lumbang dan Negororejo;

g. Kecamatan Tongas : Desa Pamatan dan Klampok.

\section{Hambatan dan Kendala Pengembangan Kawasan Agropolitan}

Hambatan dan kendala yang harus menjadi perhatian utama dalam pengembangan kawasan adalah:

- kondisi jalan produksi dan desa yang kurang baik, terutama di kawasan agropolitan Timur,

- masih kurangnya sarana dan prasarana pemasaran komoditi pertanian dan peternakan, terutama pasar tani dan subterminal agribisnis,

- masih kurangnya upaya peningkatan kualitas kelompoktani (kualitas SDM dan kinerja kelompoktani) dalam pelaksanaan agribisnis,

- masih kurangnya kegiatan pengolahan hasil pertanian (kentang, mangga), perkebunan (kopi), peternakan (susu sapi) dan kehutanan (madu). Beberapa produk olahan yang masih lemah dalam strategi pemasaran antara lain : permen dan stik susu sapi, kopi robusta dan arabika bubuk, sirup mangga, dan madu randu.

- Program dan Kegiatan Mendukung Pengembangan Kawasan Agropolitan.

Program dan kegiatan yang mendukung keberhasian pengembangan kawasan agropolitan Kabupaten Probolinggo difokuskan pada peningkatan sistem agribisnis di kawasan, antara lain:

- Peningkatan produksi usahatani hortikultura, perkebunan dan peternakan,

- Peningkatan usaha pengolahan hasil pertanian, perkebunan dan peternakan, baik jenis produk maupun kualitasnya.

- Peningkatan pemasaran hasil pertanian, perkebunan dan peternakan dan produk olahannya, terutama ke pasar luar kabupaten dan luar provinsi Jawa Timur melalui subterminal agribisnis agropolitan Kabupaten Probolinggo,

- Peningkatan kunjungan wisatawan ke lokasi wisata di kawasan agropolitan terutama destinasi agrowisata kebun strawberry dan durian.

- Peningkatan dukungan kelembagaan terhadap kegiatan agribisnis di kawasan agropolitan, antara lain lembaga keuangan, UKM, lembaga pemasaran dan kemitraan dengan perusahaan besar.

\section{Keterkaitan Sektoral dalam Pengembangan Kawasan Agropolitan}

Pengembangan kawasan agropolitan merupakan upaya pembangunan yang terpadu dan bersifat lintas sektor, sehingga diperlukan sinergi antar PD dalam penyusunan program dan kegiatan. PD yang terkait dengan pengembangan kawasan ini antara lain: PD yang membidangi Pertanian, PD yang membidangi Perkebunan dan Kehutanan, PD yang membidangi Peternakan, PD yang membidangi Perindustrian dan Perdagangan, PD yang membidangi Koperasi UKM, PD yang membidangi Kebudayaan dan Pariwisata, Badan Ketahanan Pangan dan Pelaksana Penyuluhan Pertanian (BKP4), PD yang membidangi Pekerjaan Umum (Cipta Karya, Bina Marga, Pengairan), Badan Lingkungan Hidup, Badan Pemberdayaan Masyarakat, PD yang membidangi Perhubungan dan Kantor Penanaman Modal dan Perijinan. Keterkaitan sektoral tersebut perlu ditingkatkan, baik secara horizontal 
antar PD di Kabupaten Probolinggo maupun vertical dengan kantor/lembaga terkait di tingkat Provinsi Jawa Timur dan di tingkat nasional.

\section{Monitoring dan Evaluasi Pengembangan Kawasan Agropolitan}

Monev khusus terkait upaya pengembangan kawasan agropolitan masih harus ditingkatkan dengan membentuk kelompok kerja (pokja) khusus yang mengawasi pertumbuhan kawasan agropolitan. Pokja tersebut merupakan tim teknis yang mengawasi kawasan agropolitan, dimana pendamping agropolitan tergabung di dalamnya.

\section{Rekomendasi}

Berdasarkan kesimpulan tersebut diatas, rekomendasi bagi Pengembangan Kawasan Agropolitan Kabupaten Probolinggo, sebagai berikut:

1. Kawasan Agropolitan Kabupaten Probolinggo

Pemerintah Kabupaten Probolinggo perlu meningkatkan kegiatan sosialisasi kepada masyarakat pelaku agribisnis di kawasan agropolitan tentang pentingnya peran aktif masyarakat dalam mengembangkan potensi pertanian, perkebunan, kehutanan dan pariwisata dalam rangka memajukan kawasan agropolitan. Peran aktif tersebut harus diwujudkan dalam penyusunan musrenbang khusus terkait kawasan agropolitan. Selain itu, diharapkan adanya peningkatan kerjasama antar daerah yang berbatasan dengan kawasan agropolitan, seperti Kabupaten Lumajang, Jember dan Pasuruan. Dan Kota Probolinggo.

2. Komoditi Unggulan di Kawasan Agropolitan Dibutuhkan upaya-upaya strategis untuk mempertahankan dan meningkatkan daya dukung lahan dan sumberdaya air bagi pengembangan komoditi unggulan secara berkelanjutan. Upaya tersebut antara lain: meningkatkan kualitas kesuburan lahan pertanian, meningkatkan ketersediaan pakan ternak, bibit/benih tanaman, dan konservasi ekologi pertanian. Dibutuhkan adanya kajian potensi dan daya dukung lahan di kawasan agropolitan. Selain itu, diperlukan kajian mengenai strategi peningkatan produk olahan pertanian/ peternakan (agroindustri) untuk meningkatkan nilai tambah komoditi dan kesejahteraan keluarga petani.

3. Desa-desa Prioritas di Kawasan Agropolitan

Desa-desa yang diprioritaskan dalam pembangunan kawasan agropolitan diharapkan dapat mendukung kebijakan tersebut melalui penggunaan dana desa yang efektif. Selain itu, lokasi kegiatan PD diharapkan lebih banyak diarahkan pada desa-desa tersebut. Sehingga kemajuan dan pertumbuhan ekonomi di desa-desa prioritas tersebut dapat menjadi pendorong dan penghela bagi pertumbuhan ekonomi di desadesa lain disekitarnya.

4. Program dan Kegiatan Mendukung Pengembangan Kawasan Agropolitan

Dibutuhkan peningkatan inovasi program dan kegiatan dari seluruh PD terkait dalam rangka mendukung pengembangan kawasan agropolitan Kabupaten Probolinggo. Selain program dan kegiatan yang telah ditetapkan dalam Permendagri Nomor 13 Tahun 2006, diharapkan PD menyusun kegiatan yang sesuai dengan kebutuhan masyarakat di kawasan agropolitan. Kegiatan tersebut bersifat spesifik lokasi dan memiliki target yang jelas secara kuantitatif dan kualitatif. Misalnya, program pengembangan agribisnis sayur dan buah-buahan organic atau ramah lingkungan di desa Sukapura.

5. Keterkaitan Sektoral dalam Pengembangan Kawasan Agropolitan 
Guna meningkatkan keserasian dan sinkronisasi antar program PD dalam mendukung pengembangan kawasan agropolitan diperlukan pembentukan kelompok kerja (pokja) PKA yang terdiri dari unsur-unsur dari setiap PD. Sehingga terjadi komunikasi dan pertukaran informasi yang lebih intensif antar PD dalam kerangka mendukung keberhasilan pengembangan kawasan agropolitan Kabupaten Probolinggo. Pembentukan pokja kawasan agropolitan dapat ditetapkan dengan surat keputusan bupati (SK Bupati).

6. Diharapkan masterplan ini segera ditindaklanjuti dengan kajian kelayakan pembangunan pasar tani dan subterminal agribisnis yang bertujuan mendukung pembangunan agropolis (mainland) dan seluruh wilayah pendukungnya (hinterlandnya).

7. Diharapkan masterplan ini segera ditindaklanjuti dengan kajian kelayakan moda angkutan komoditi pertanian, peternakan dan kehutanan sehingga arus barang dan manusia di kawasan agropolitan dapat lebih efisien.

\section{DAFTAR PUSTAKA}

Badan Pusat Statistik, 2015. Kabupaten Probolinggo Dalam Angka, Kabupaten Probolinggo.

Bappeda Kabupaten Probolinggo, 2014. Penyusunan Rencana Program Investasi Jangka Menengah (RPIJM) Pengembangan Kawasan Agropolitan Kabupaten Probolinggo Tahun 2014, Kabupaten Probolinggo.

----------, 2015. Rencana Pengembangan Produk Unggulan (PUD) Kabupaten Probolinggo Tahun 2015. Kabupaten Probolinggo.

Bappeda Provinsi Jawa Timur, 2015. Pedoman Umum Pengembangan Kawasan Agropolitan dan Minapolitan Provinsi Jawa Timur.

Erna Rustiadi, 2009. Penataan Ruang Kawasan Perdesaan dan Agropolitan Sebagai Strategi Pembangunan Perdesaan, Kementerian Pekerjaan Umum Dirjen Cipta Karya. Jakarta.

Kementerian Pekerjaan Umum Dirjen Cipta Karya, 2012. Agropolitan dan MinapolitanKonsep Kawasan Menuju Keharmonian. Jakarta.

Miftakhul Huda dkk, 2014. Pengembangan Daya Saing Daerah Kabupaten/Kota di Provinsi Jawa Timur Berdasarkan Potensi Daerahnya. Jurnal Teknik Pomits Vol. 3 No. 2 tahun 2014. Fakultas Teknik Sipil dan Perencanaan ITS Surabaya, Surabaya.

Soenarno, 2003. Pengembangan Kawasan Agropolitan Dalam Rangka Pengembangan Wilayah, Departemen Permukiman dan Prasarana Wilayah, Jakarta. 